(๑) Entomologica Fennica. 27 June 1995

\title{
On the Miridae fauna of the Middle East (Heteroptera, Miridae)
}

\author{
Rauno E. Linnavuori
}

Linnavuori, R. E. 1995: On the Miridae fauna of the Middle East (Heteroptera, Miridae). - Entomol. Fennica 5:205-212.

The taxonomy of the genera Tuponia Reuter, 1875, and Cyrtopeltis Fieber, 1860, is discussed. New species: Tuponia semele and T. filomele spp. $\mathrm{n}$. (Israel). New combination: Tarajala brevicornis (Reuter, 1879) = Tuponia brevicornis (Reuter, 1979). New synonymies: Tuponia annulata Wagner, $1974=$ T. carayoni vulnerata Linnavuori, 1961, T. dentifer Wagner, $1974=T$. macedonica Wagner, 1957, T. sodomita Wagner, 1974, = T. guttata Wagner, 1950, and Cyrtopeltis khalafi Seidenstuicker, $1964=$ C. pygmaea Wagner, 1956.

Linnavuori, R. E., Somersoja, FIN-21220 Raisio 22, Finland

Received 10 January 1994, accepted 10 February 1995

The article is based on my field work in Israel in 1986, during which special attention was paid to the highly interesting Negev desert. The material collected is the property of the American $\mathrm{Mu}$ seum of Natural History, but is at present in the author's collection at Raisio.

\section{Phylinae}

Tuponia (Tuponia) carayoni vulnerata Linnavuori, 1961

(Fig. 1a-b)

Tuponia lethierryi vulnerata Linnavuori 1961:24-25.

Tuponia vulnerata Drapolyuk 1980:54.

Tuponia carayoni vulnerata Linnavuori 1986:183.

Tuponia hungarica Benedek \& Jászai 1968:10-13 (Drapolyuk 1980:54).

Tuponia annulata Wagner 1974:143-144, syn. n.

Material: Israel: many exx from Be'er Mashabbim, 22.IV.1986; Be'er Sheva, 29.IV.1986; Dishon, 6.V.1986; 'Ein Avdat, 10.VIII.1986; Elifaz near Timna, 19.IV.1986; 'En Aqrabbim, 31.VII-9.VIII.1986; Hazeva, 15.IV.1986; Mt. Ramon, Es Saharonim, 9-10.VII.1986; Nahal Arugot, 22.VII.1986; Neot Hakikkar, 16-20.VII.1986; Newe Zohar, 28.IV.1986; Yad Hashmona near Qiryat Anavim, 10.VI.1986;
Yeroham, 20.IV.1986; 10-15 km N Yotvata, 23.IV.1986, Limnavuori. Palestine: Jericho, 1 ex, 5.V.1962, Eckerlein. Jordan: Wadi Mujib, 1 ex, 1.V.1962, Eckerlein.

A well-known species, descriptions in Drapolyuk 1980:54-56 and Linnavuori 1961:25 and 1986:181-183 not repeated. Easily recognized by the shape of the vesica (Fig. 1a).

Discussion: Wagner (1974:143-144) described $T$. annulata on the basis of the circularly curved vesica. In the Neot Hakikkar population studied one male has a circularly curved vesica as in Wagner's original illustration (Fig. 1b), while in five other males it is of the regular shape of vulnerata. Likewise, in an immature male collected from the vicinity of Yotvata it is nearly circular, in the other specimens of the usual vulnerata shape. Since no other morphological differences between annulata and vulnerata were found, both taxa are regarded as conspecific. The circularly curved vesica is undoubtedly anomalous and apparently caused by immaturity.

Biology: On Tamarix.

Distribution: A common Pontomediteranean species. 

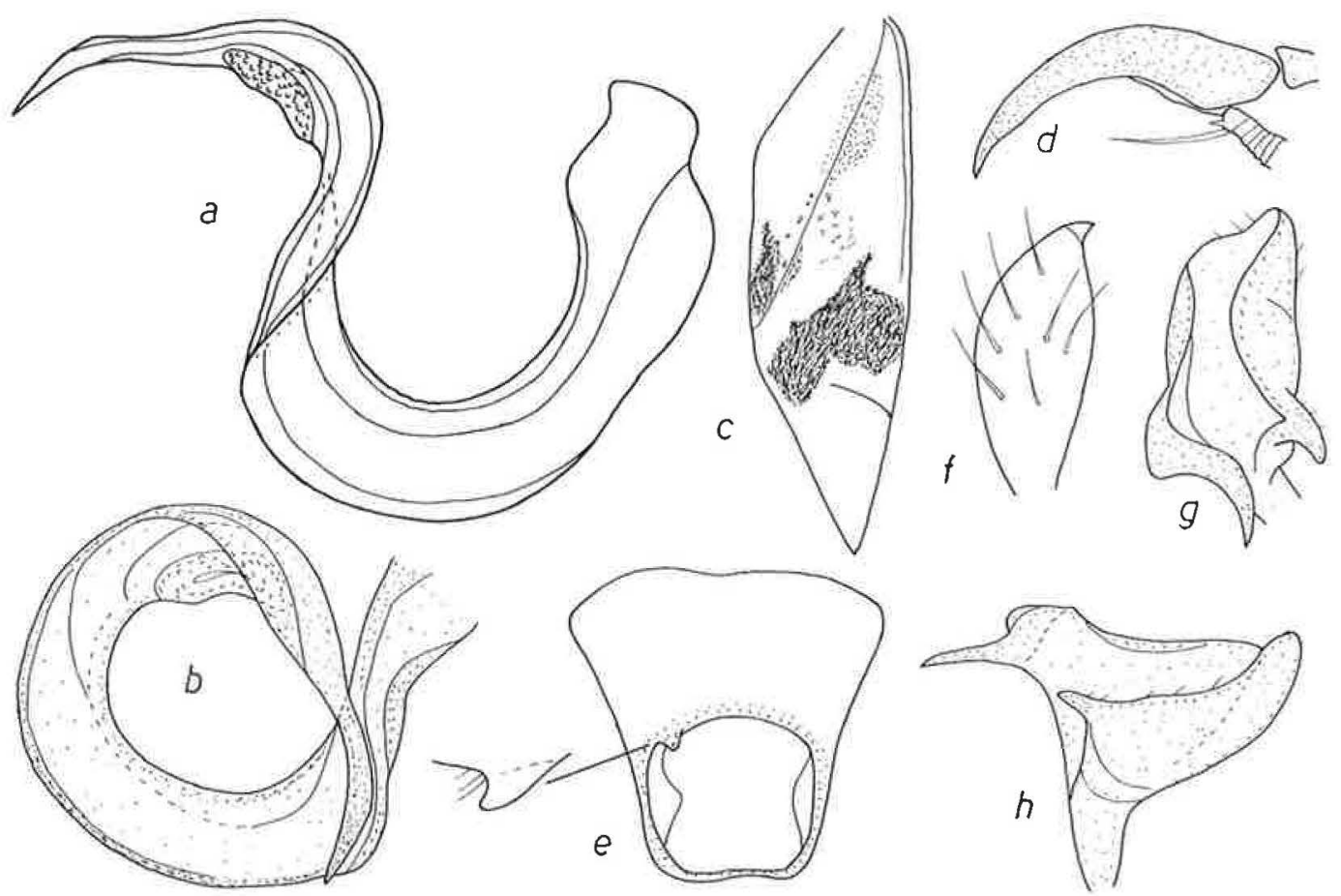

Fig. 1. Tuponia carayoni vulnerata Linnavuori. a: vesica (slide mount), ex from Hula, Israel; b: vesica of an abnormal ex from Neot Hakikkar. - T. semele sp. n. c: elytron; d: claw; e: pygofer, dorsal view; f: right style; g-h: left style in dorsal and lateral view.

Tuponia (Tuponia) macedonica Wagner, 1957 (Fig. 2a-b)

Tuponia eckerleini macedonica Wagner 1957:258-260. Tuponia macedonica Josifov 1961:21-24.

Tuponia dentifer Wagner 1974:141-143, syn. n.

Types: Cyprus: Ayios Amvrosius, or holotype, 2 우 paratypes of dentifer, 25.VI.1972, Eckerlein, in Mus. Hamburg.

Material: Bulgaria: 4 exx, 4.VI.1959, Josifov. Turkey: Pozanti (Taurus), 8 exx, 24.V.1960, Eckerlein, in coll. Linnavuori.

A well-known species, descriptions in Wagner 1975:430 and Josifov 1961 not repeated.

Male genitalia: Left side of base of genital opening with blunt tubercle as in T. semele. Vesica (Fig. $3 \mathrm{a}-\mathrm{b})$ long and gracile, with two apical appendages of inequal length, the shorter one falcate and edentate, the longer one scoop-like, basally constricted, with outer margin coarsely dentate, a blunt lateral process at gonopore also present.
Discussion: An examination of the holotype of $T$. dentifer revealed that the male genitalia are identical with those of $T$. macedonica. Consequently, $T$. dentifer is a strict synonym of $T$. macedonica.

Distribution: Known from the Balkan Peninsula, Turkey and Cyprus.

Tuponia (Tuponia) semele sp. $\mathrm{n}$.

(Figs. 1c-h, 3a-e)

Material: Israel: Hazeva, ơ holotype, 15.IV.1986; Wadi Paran, 10 paratypes, 20.IV.1986; 10-15 km N Yotvata, 8 paratypes, 23.IV.1986; Ze'elim, 1 paratype, 22.IV.1986, Linnavuori. Jordan: Wadi Mujib, 3 paratypes (identified as elegans by Wagner), 1.V.1962, Eckerlein, in coll. Linnavuori.)

Diagnosis: Of the group of species in which the pygofer is truncate apically and provided with a tubercle on the left side of the base of the genital opening, and the apex of the vesica has one broad 


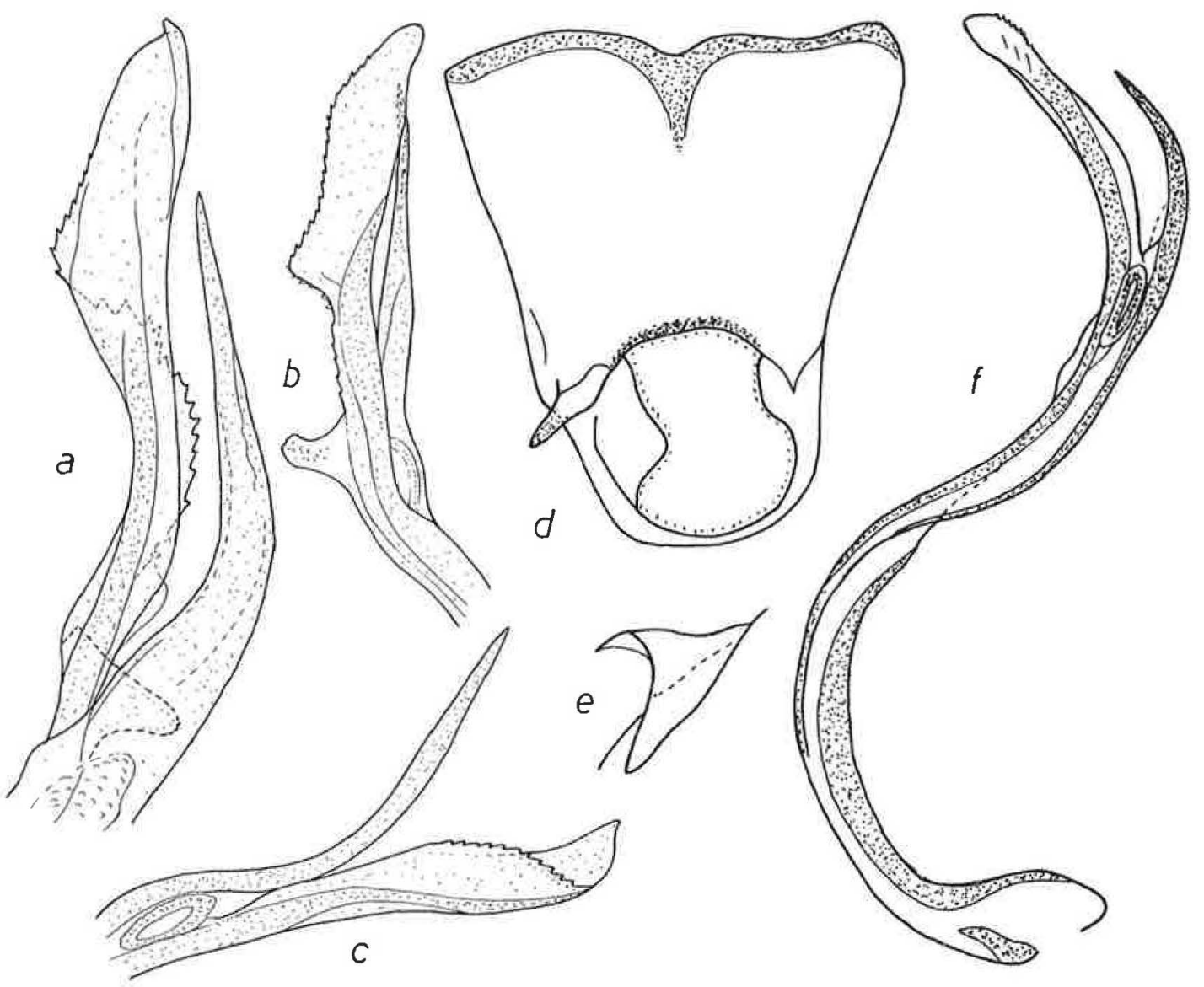

Fig. 2. Tuponia macedonica Wagner. a-b: apex of vesica (slide mount) in two aspects (a ex from Burgas, Bulgaria, b holotype of dentifer). - T. roseipennis Reuter (ex from Turkestan). c: apex of vesica in slide mount. - T. pungens Linnavuori. d: pygofer, dorsal view; e: lateral tubercle of pygofer; f: vesica (slide mount) in lateral view.

and one falcate process. The closest relative is $T$. bifasciatus Wagner, 1965 from Cyprus (material studied: Cyprus, Jermasoya river (the type locality), $1 o^{7}$ and 2 oo, 7.V.1965, Mavromoustakis, in coll. Linnavuori), which also has a red pattern on the elytra and a short robust vesica. $T$. bifasciatus differs in the presence of a red spot on the cuneus, smaller eyes (ocular index 1.4-1.5 in o $\sigma^{7}, 1.85-1.90$ in $Q$ ) and structure of the vesica (Fig. $3 \mathrm{f}-\mathrm{g}$ ): a narrow lobe present at base of the nearly edentate scoop-like process, the falcate process provided with a ridge with two rows of tubercles. The other species of the group, T. pungens Linnavuori, 1986 (Saudi Arabia; Fig. 2d-f), T. roseipennis Reuter, 1878 (Middle Asia; Fig. 2c) and T. macedonica Wagner, 1957 (Pontomediterranean; Fig. 2a-b), at least males lack a red pattern on the elytra. Moreover, the vesica is longer, more gracile and provided with dissimilar apical processes.

Description: Length $3.25-3.5 \mathrm{~mm}$. Whitish gray. Head, antennae and pronotal calli pale yellow. Eyes brown. Basal margin of scutellum bright yellow. Elytra with red pattern: arcuate transverse spot on apex of corium, elongate dash on apex of clavus, and elongate area along middle of claval suture on clavus and the adjacent part of corium; cuneus pale; membrane brownish; veins pale. Under surface and legs whitish, apices of hind femora with a few brown dots; tibial spines black.

Body about $2.8 \times$ as long as broad at base of pronotum, elongately ovate. Hair covering on 


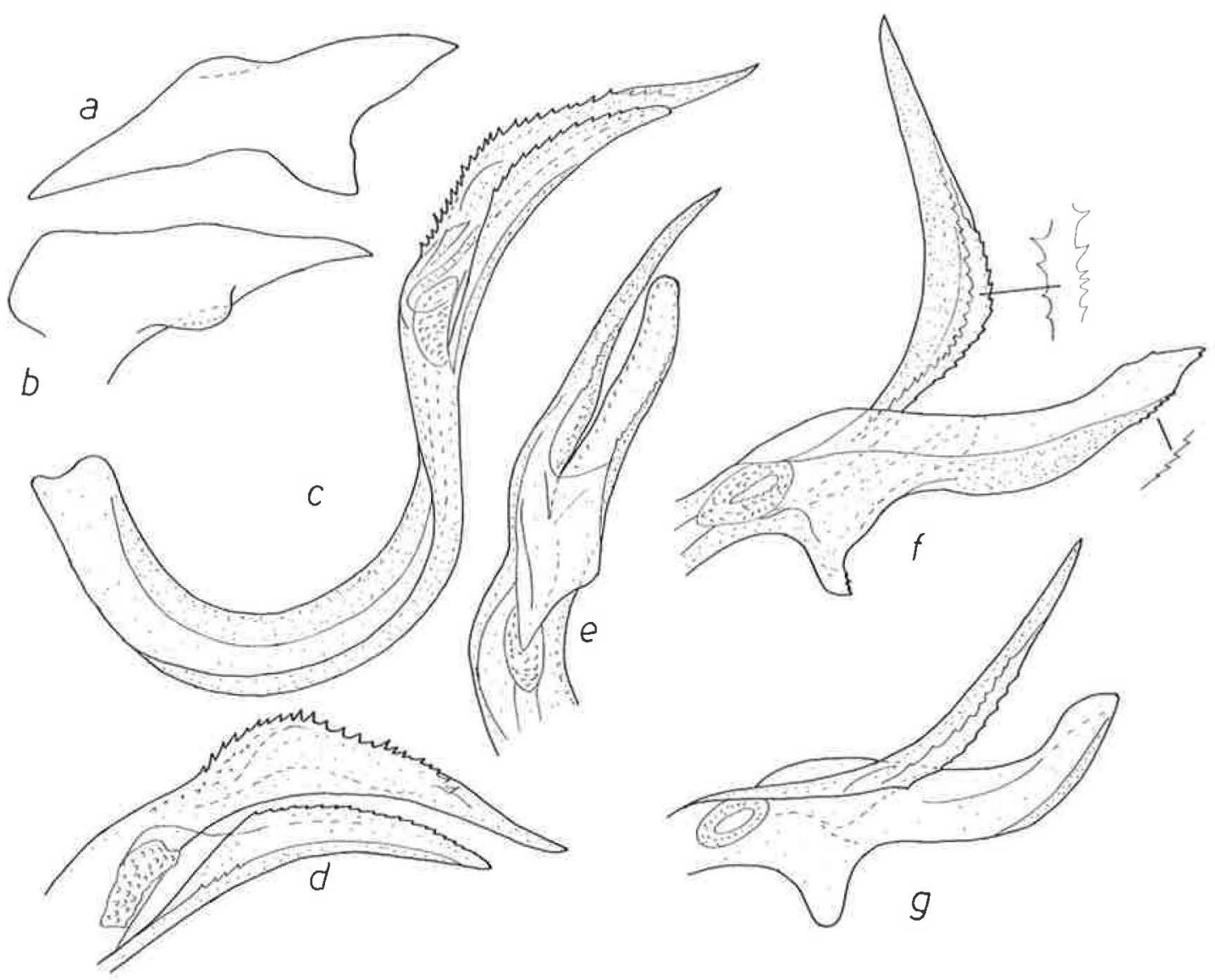

Fig. 3. Tuponia semele sp. n. a-b: theca; c: vesica in slide mount, lateral view; d-e: apex of vesica in slide and dry mount. - T. bifasciata Wagner. $\mathrm{f}-\mathrm{g}$ : apex of vesica in slide and dry mount.

upper surface pale, a few dark hairs also present on apical part of elytra. Head $0.71-0.73\left(0^{7}\right)$ or $0.7($ ( ) $\times$ as broad as basal width of pronotum; ocular index 1.23-1.30 (ơ), 1.55-1.67 (o). Antennae gracile, proportions between joints 14:65:47:20 (ơ), 13:64:55:22(Q), 2nd segment $1.24-1.30\left(\sigma^{7}\right)$ or $1.16-1.22(Q) \times$ as long as diatone, $0.90-0.93\left(0^{7}\right)$ or $0.80-0.85(Q) \times$ as long as basal width of pronotum. Rostrum extending to base of venter. Claws (Fig. 1d) with tiny remnants of pulvilli.

Male genitalia (Figs. 1e-h, 3a-e): Pygofer truncate apically, left side of base of genital opening with blunt tubercle. Theca sharp-tipped, with round subbasal lobe. Vesica robust, relatively short, basal part broadly U-shaped; two apical processes, the shorter process scoop-like, with outer margin finely dentate, the longer appendage falcate, with coarsely dentate ridge.

Biology: On Tamarix.

Etymology: Greek mythology, Semele, mother of Dionysos.

Discussion: Wagner (1975:426-427) mixed T. semele with $T$. elegans (Jakovlev, 1867) $(=T$. bilobata Benedek \& Jászai, 1968, synonymy after Drapolyuk 1980:56) (a common Pontomediterranean species): his record of elegans from Jordan actually refers to semele. T. elegans and the related species T. altera Wagner, 1974 (common in the Negev desert in Israel) are also omamented with an intense red pattern on the elytra, but are readily distinguished from $T$. semele and its relatives by the narrowly conical and edentate pygofer. The vesica of both species is illustrated in Fig. 4a-e. 


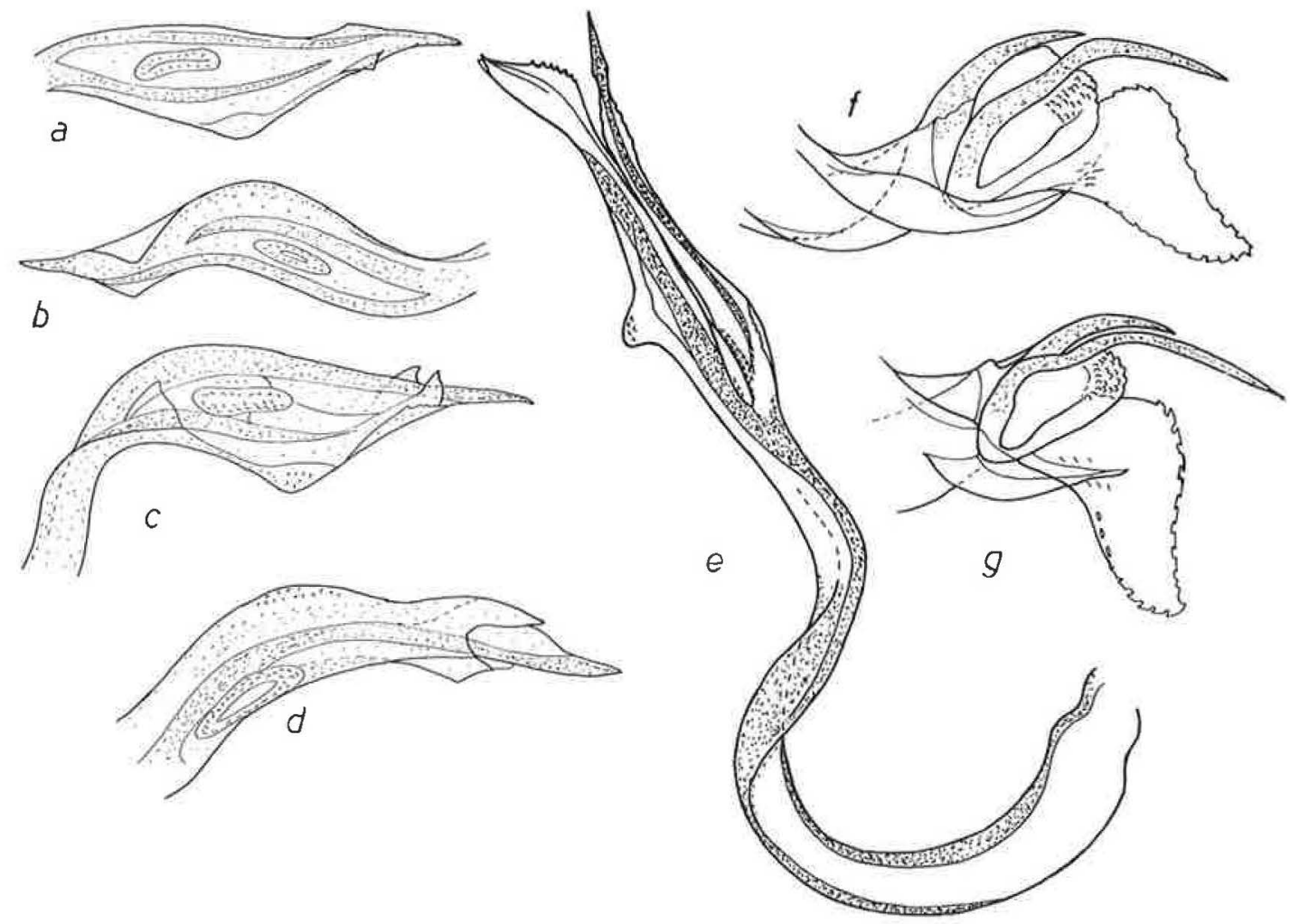

Fig. 4. Tuponia elegans (Jakovlev). a-d: apex of vesica in different views ( $a-b$ in dry, c-d in slide mount, a and c of paratype of bilobata, $b$ and $d$ of ex from Karakum). - T. altera Wagner (paratype). e: vesica (slide mount). T. guttata Wagner. f-g: apex of vesica in slide mount (exx from Cairo and Anbar-Abad, Iran).

Tuponia (Chlorotuponia) guttata Wagner, 1950 (Figs. 4f-g, 5a)

Tuponia guttata Wagner 1950:147-149.

Tuponia variegata Wagner 1958:11 (Linnavuori 1986:186). Tuponia sodomita Wagner 1974:144-145, syn. n.

Types: Israel: Dead Sea, Ein Faskha, ơ holotype and 20 paratypes of sodomita, 16.V.1972, Eckerlein, in Mus. Hamburg.

Material: Israel: Numerous exx from Be'er Mashabbim, 22.IV.1986; Be'er Sheva, IV-V.1986; Beit Lahiya, 26.IV.1986; 'Ein Avdat, 10.VIII.1986; Hazeva, 15.IV.1986; Hula Nat. Res., 15.VI.1986; Nahal Arugot, 22.VII.1986; 10-15 km N Yotvata, 24.IV.1986; Ze'elim, 6.VII.1986, Linnavuori.

A well-known species. Taxonomy treated in Wagner 1975:441-442 and Linnavuori 1986:185186. Easily recognized by the shape of the vesica (Figs. 4f-g, 5a), which is provided with three apical processes, two of them falcate, the third one foot-shaped, marginally coarsely dentate.

Discussion: An examination of the holotype of T. sodomita revealed that the vesica is completely identical with that of $T$. guttata. Consequently $T$. sodomita is a strict synonym of the latter.

Biology: On Tamarix.

Distribution: Eremian, extending from Egypt to Iran.

Tuponia (Chlorotuponia) filomele sp. $\mathrm{n}$. (Figs. 5b-f, 6a-b)

Material: Israel: Wadi Paran, $0^{\lambda}$ holotype, o paratype, 20.IV.1986; Zuqim, $50 \mathrm{~km} \mathrm{~N}$ Yotvata, $\sigma^{\prime}$ and $o$ paratype, 24.IV.1986, Linnavuori, in coll. Linnavuori.

Diagnosis: Related to $T$. canariensis Wagner, 1954, and T. oculata Wagner, 1954, from the 


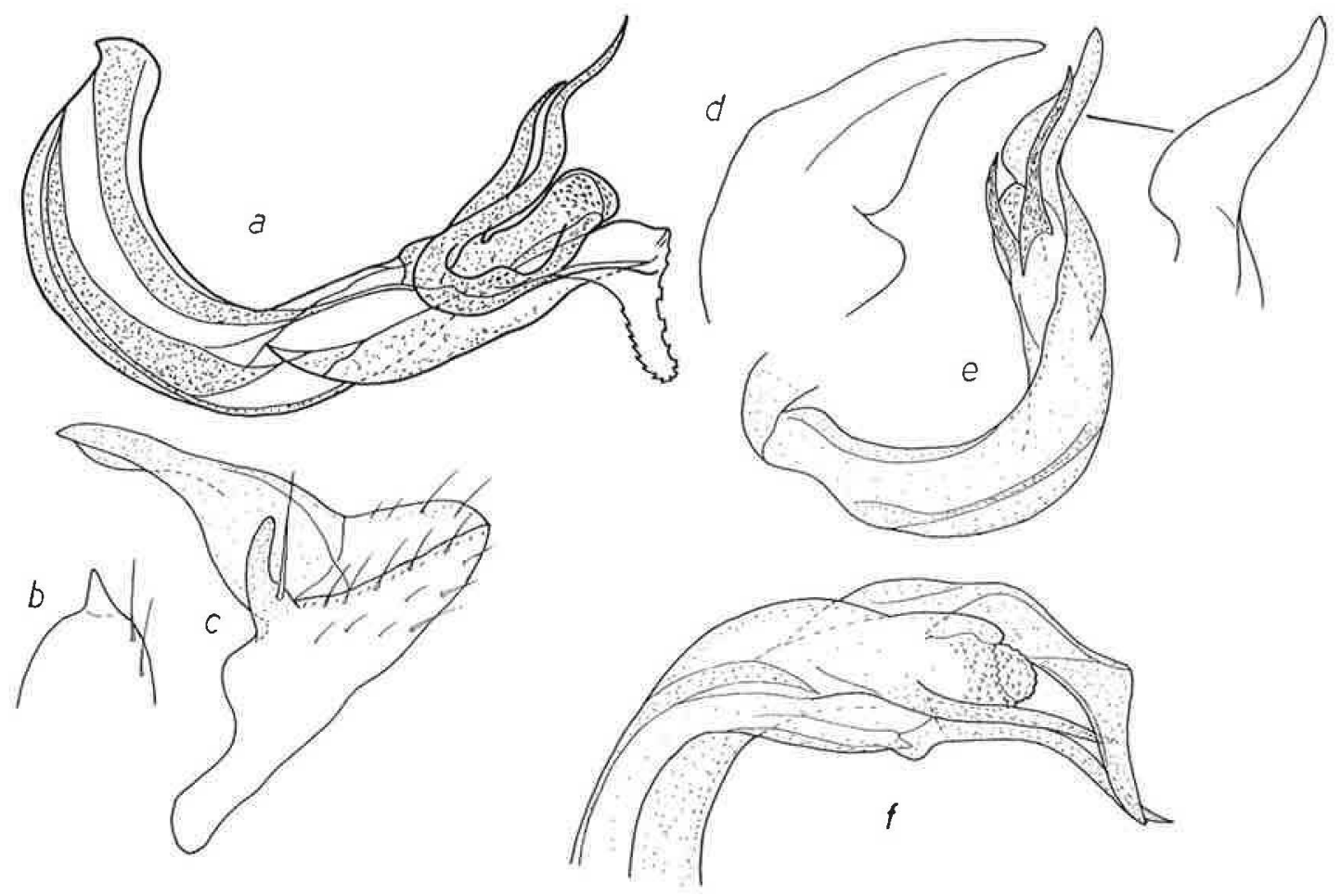

Fig. 5. Tuponia guttata Wagner (ex from Dawra, Iraq). a: vesica in slide mount. - T. filomele sp. $\mathrm{n}$. b: apex of right style; c: left style in lateral view; $d$ : theca; e: vesica in slide mount (holotype); $f$ : apex of vesica in slide mount (paratype from Wadi Paran).

Canary Islands, which differ in the vestiture (upper surface with dark and pale hairs) and in the structure of the vesica (Fig. 6c-d): the gracile paired apical processes are longer and the unpaired lamellate appendage is shorter, footshaped and provided with a distinct heel. The heel in $T$. canariensis is blunt, in $T$. oculata sharp. In T. guttata Wagner and the related species the lamellate process is coarsely dentate.

Description: Length ơ $2.50-2.75 \mathrm{~mm}, \varnothing 2.50$ $\mathrm{mm}$. Pale or yellowish green. Eyes brown. Antennae yellow. Membranes of elytra brownish smoky. Legs yellowish, under surface of hind femora with indistinct brownish dots, tibiae immaculate, tibial spines black. In female elytra brighter green with exocorium pale.

Male. Body parallel-sided, about $3.2 \times$ as long as broad at base of pronotum. Q. Body elongately ovate, $2.9 \mathrm{x}$ as long as broad at base of pronotum. Hair covering of upper surface pale. Head $0.9\left(\bigcirc^{7}\right)$ or $0.86(q) \times$ as broad as basal width of pronotum. Eyes in $O^{7}$ large, ocular index 1.14-1.44 ( $\left(^{\top}\right), 2.18(\emptyset)$. Proportions between antennal joints 12:54:42:24( $\left(\sigma^{\top}\right), 11: 45: 37: 20($ ()),

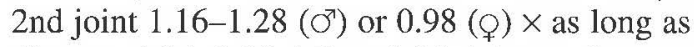
diatone, 1.04-1.13 $\left(\sigma^{7}\right)$ or $0.83(\varnothing) \times$ as long as basal width of pronotum. Rostrum extending to hind coxae. Pronotum $2.2\left(\sigma^{7}\right)$ or $2.35(Q) \times$ as broad as long in middle. Hind tibia $1.7\left(\sigma^{\top}\right)$ or 1.5 $($ Q) $\times$ as long as basal width of pronotum. Proportions between hind tarsomeres 6:11:13.

Male genitalia (Figs. 5b-f, 6a-b): Pygofer narrowly conical. Right style small, ovate. Left style: hypophysis long and straight, sensory lobe with long plug-like apical process. Theca claw-like. Vesica shallowly U-shaped, twisted; apex with relatively long, edentate lamellate process resembling a bird's head and with two gracile appendages.

Biology: On Tamarix.

Etymology: Filomele, daughter of Pandion, king of Athens, a character in Ovidius' Metamorphoses. 


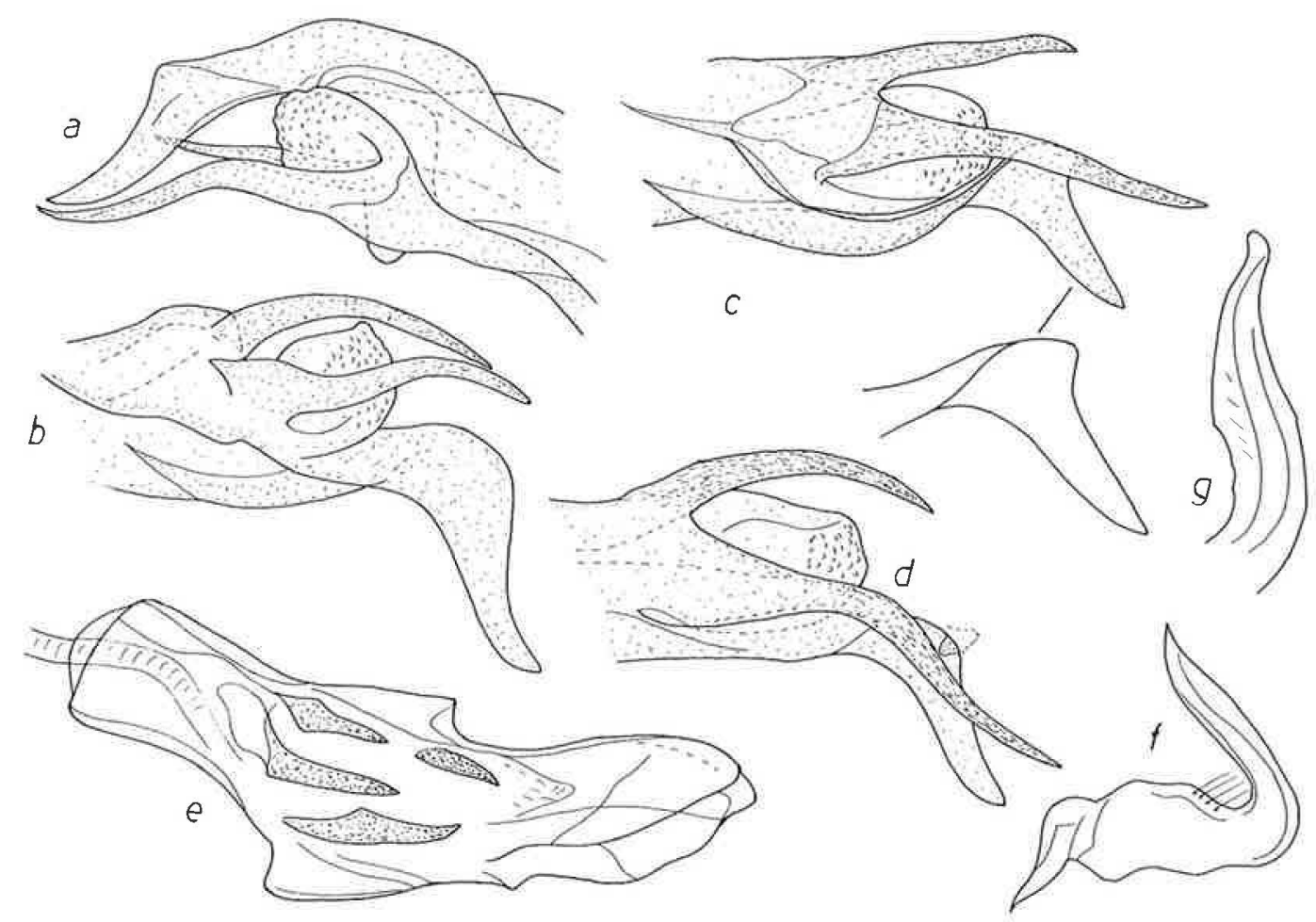

Fig. 6. Tuponia filomele sp. n. a-b: apex of vesica in slide mount (a of paratype from Wadi Paran, b of paratype from Zuqim). - T. canariensis Wagner. c: apex of vesica in slide mount. - T. oculata Wagner. d: apex of vesica in slide mount. - Cyrtopeltis pygmaeus Wagner. e: aedeagus; f: left style; g: hypophysis of left style (holotype) in broad aspect.

Tuponia (Chlorotuponia) brevicornis (Reuter, 1879), comb. n.

Atomoscelis brevicornis Reuter 1879a:39.

Tarajala brevicornis Wagner 1966:13-14 and Drapolyuk 1982:150.

Tuponia punctipes Reuter 1879b:296 (Drapolyuk 1982:150).

Tuponia brevicornis Reuter 1890:248 nec brevicornis Reuter 1879 (Drapolyuk 1982:150).

Material: Israel: many exx from Be'er Mash'abbim, 4.VI.1986; Be'er Sheva, IV-VI.1986; Revivim, 4.VI.1986, Linnavuori.

A redescription in Linnavuori 1961:30-31 and Wagner 1975:451 is not repeated here.

Discussion: Drapolyuk (1982:150) and Wagner (1966) regarded Atomoscelis brevicornis Reuter as a member of the genus Tarajala Wagner. As pointed out by Linnavuori (1993:170) Tarajala is a synonym of Ellenia Reuter, 1910, which in turn is identical with Moissonia Reuter, 1894 (Linnavuori \& Al-Safadi 1993). Moissonia, which is recognized by the fleshy parempodia of the claws, for example, is not closely related to Tuponia. Atomoscelis brevicornis displays all the main characters of Tuponia and is therefore a representative of that genus. As pointed out by Drapolyuk, Tuponia punctipes Reuter, 1879b, and T. brevicornis Reuter, 1890, are synonyms of $T$. brevicornis (Reuter, 1879).

Biology: On Tamarix.

Distribution: Irano-Turanian, previously known from Turkey, Iraq, Iran, and Central Asia.

\section{Dicyphinae}

Cyrtopeltis (Campyloneuropsis) pygmaea

Wagner, 1956

(Fig. 6e-g)

Cyrtopeltis pygmaea Wagner 1956:1-3.

Cyrtopeltis khalafi Seidenstücker 1964:237-239, syn. n. 
Types: Egypt: Abusir, o holotype and $ᄋ$ paratype of pygmaea, 8.I.1955, H. Priesner; St. Katrien, O’ paratype of pygmaea, 16.V.1934, H. Priesner, in Mus. Hamburg.

Material: Israel: several exx from Be'er Sheva, IV.1986; Ein Avdat, 10.VIII.1986; Elat, 17.IV.1986; Elifaz near Timna, 23.VI.1986; 'En Gedi, 23.VII.1986; Mt. Ramon, Es Saharonim, 13.VII.1986; Nahal Arugot, 22.VII.1986; Ne'ot Hakikkar, 16-20.VII.1986; Yad Hashmona, 10.VI.1986; Zofar, 24.IV.1986, Linnavuori. Finds from Egypt, the Sudan and Saudi Arabia listed in Linnavuori 1964:323, 1975:15 and 1986:129.

Discussion: C. pygmaea and C. khalafi were distinguished by the following characters: 1) size: pygmaea $1.85-2.05 \mathrm{~mm} \sigma^{\top}, 1.95-2.05 \mathrm{~mm}$, khalafi $2.9 \mathrm{~mm}{ }^{\pi}, 3.2 \mathrm{~mm}$,, 2$)$ shape of left style: hypophysis short in pygmaea (Figures 5 and 6 in Wagner 1956:2), long, blade-like in khalafi (Figures 3-5 in Seidenstuicker 1964:238), 3) structure of vesica: in pygmaea with two spicula (Fig. 9c, drawn by Seidenstücker, in Linnavuori 1975:14), with four spicula in khalafi (Fig. 1 in Seidenstïcker 1964:238). The following comments are based on the examination of extensive material from the Middle East. Size: actual length in the material studied 2.0-2.75 $\mathrm{mm}\left(\mathrm{O}^{\mathrm{O}} \mathrm{O}\right)$ in Egyptian and Sudanese populations, $2.75-3.2 \mathrm{~mm}$ in eastern ones, while populations from Israel are mixed in size. Left style: hypophysis always long, blade-like (Fig. 6fg); Wagner's original illustration was apparently drawn from a specimen with a broken hypophysis. Vesica: always with four spicula (Fig. 6e). Since no actual differences between the two taxa were found, they are considered as conspecific.

Biology: On Hyoscyamus. Also recorded from Trichodesma africanum.

Distribution: Eremian, extending from Egypt and northern Sudan to the Arabian Peninsula and Iraq.

\section{References}

Benedek, P. \& Jászai, V. E. 1968: On some species of the genus Tuponia Reuter, 1875 (Heteroptera, Miridae, PhyIinae). - Acta Zool. Acad. Sci. Hungaricae 14: 7-13.
Drapolyuk, I. S. (Драполюк, И. С.) 1980: Review of capsid bugs of the subgenus Tuponia s. str. (Heteroptera, Miridae) from the USSR and Mongolia. (In Russian) - Insects of Mongolia 7: 43-68.

- 1982: Review of capsid bugs of the genus Chlorotuponia (Heteroptera, Miridae) from the USSR and Mongolia. (In Russian) - Insects of Mongolia 8: 148-183.

Josifov, M. 1961: Über drei in Bulgarien anzutreffende Miridenarten (Hemiptera, Heteroptera). - Fragmenta Balcanica 4(3): 21-26.

Linnavuori, R. E. 1961: Hemiptera of Israel II. - Ann. Zool. Soc. Vanamo 22(7): 1-51.

- 1975: Hemiptera of the Sudan, with remarks on some species of the adjacent countries. 4. Miridae and Isometopidae. - Ann. Zool. Fennici 12(1): 1-118.

- 1986: Heteroptera of Saudi Arabia. - Fauna of Saudi Arabia 8: 31-197.

- 1993: The Phylinae (Hemiptera: Miridae) of West, Central and North East Africa. - Garcia de Orta, Sér. Zool. Lisboa 18(1-2): 115-296.

Linnavuori, R. E. \& Al-Safadi, M. M. 1993: Nomenclatural note on the genus Moissonia Reuter (Hemiptera, Miridae, Phylinae). — Entomol. Fennica 4: 233-234.

Reuter, O. M. 1979a: Capsidae Turkestanae. Diagnoser öfver nya Capsider från Turkestan. - Öfv. Finska Vetensk. Soc. Förhandl. 21: 141-198 (Sep. 1879, 58 pp.).

- 1979b: Hemiptera Gymnocerata Europae. Hémiptères Gymnocerates d'Europe, Du bassin de la Méditerranée et de l'Asie Russe. II. - Acta Soc. Scient. Fenn. 1979: 193-312.

- 1980: Adnotationes Hemipterologicae. - Rev. d'Entomol. 9: 248-254.

Seidenstücker, G. 1964: Beitrag zu Cyrtopeltis (Heteroptera, Miridae). - Reichenbachia 3: 237-240.

Wagner, E. 1950: Neue Hemiptera-Heteroptera aus Nordafrika. - Bull. Soc. Fouad 1 1 Entomol. 34: 143-149.

- 1957: Zur Systematik von Tuponia eckerleini E. Wagner 1955 (Hem. Het. Miridae). - Entomol. Berichten 17: 258-260.

- 1958: Heteropteren aus Iran 1954. 2. Teil. HemipteraHeteroptera (Fam. Miridae). - Jahreshefte Ver. vaterl. Naturkunde Württemberg 112: 74-100.

- 1966: Über Atomoscelis brevicornis Reuter, 1879 (Hem. Het. Miridae). - Miteil. Deutsche Entomol. Ges. 25(1): 13-14.

- 1974: Einige neue Tuponia-arten aus dem östlichen Mittelmeerraumes (Hem. Het. Miridae). — Entomol. Berichten 34: 139-148.

- 1975: Die Miridae Hahn 1831, des Mittelmeerraumes und der Makaronesischen Inseln (Hemiptera, Heteroptera). Teil 3: Phylinae.-Entomol. Abhandl. Staatl. Mus. für Tierkunde Dresden 40, Supplement. 421 pp. 